\title{
PENGARUH ENDORPHIN MASSAGE TERHADAP PENGELUARAN ASI PADA IBU POST PARTUM
}

\author{
Magfirah $^{1}$, Idwar $^{2}$ \\ 1Program Studi Kebidanan Langsa Poltekkes Kemenkes Aceh \\ 2Program Studi Kebidanan Keperawatan Poltekkes Kemenkes Aceh \\ Email : magfirah.idris79@gmail.com
}

\section{ABSTRACT EFFECT OF ENDORPHIN MASSAGE ON BREAST MILK PRODUCTION ON THE MOTHER'S POST PARTUM}

Background: Decreased levels of endorphins and oxytocin are known to be one of the factors causing breast milk production problems in the first days after birth. Low levels of these hormones are also an obstacle in exclusive breastfeeding. Endorphin Massage can provide a feeling of calm and comfort during lactation, thereby increasing the response of the posterior pituitary to producing the hormone oxytocin to increase let down reflex.

Research Objectives: to determine the effect of Endorphin Massage on Breastfeeding Expenditures in Post Partum Mothers in the Work Area of Langsa Lama Public Health Center, Langsa City.

Methods: This type of research is a quasi experiment, with a post test only control group design approach. The number of samples of 20 respondents, divided into 2 groups (Endorphin Massage and control) each of 10 respondents.

Results: The results of the independent $T$ test showed that the mean value of the Endorphin Massage treatment group was 8.50 and the control group was $4.90(0.000)$ with $p<0.05$. The results of this study indicated an increase in milk production in the group that received the Endorphin Massage compared to the control group. mothers

Conclusions There is an effect of the Endorphin Massage method on breastfeeding in post partum

suggestions: . It is hoped that health workers can apply the Endorphin Massage method to post partum mothers in an effort to increase milk production.

Keywords: Endorphin Massage, Breast Milk Production

\section{ABSTRAK}

Latar Belakang: Penurunan kadar endorfin dan oksitosin diketahui sebagai salah satu faktor penyebab masalah produksi ASI pada hari-hari pertama setelah bayi lahir. Rendahnya kadar hormon tersebut juga menjadi kendala dalam pemberian ASI Eksklusif. Endorphin Massage dapat memberikan rasa tenang dan nyaman selama masa laktasi sehingga meningkatkan respon hipofisis posterior untuk memproduksi hormon oksitosin dalam meningkatkan let down reflex.

Tujuan Penelitian: diketahui Pengaruh Endorphin Massage Terhadap Pengeluaran ASI Pada lbu Post Partum Di Wilayah Kerja Puskesmas Langsa Lama Kota Langsa.

Metode Penelitian: Jenis penelitian quasi experiment, dengan pendekatan post test only control group design. Jumlah sampel 20 responden, dibagi menjadi 2 kelompok (Endorphin Massage dan kontrol) masingmasing 10 responden.

Hasil Penelitian: Hasil uji independen $T$ test didapatkan nilai rerata kelompok perlakuan Endorphin Massage sebesar 8,50 dan kelompok kontrol 4,90 $(0,000)$ dengan $p<0,05$. Hasil penelitian ini menunjukkan adanya peningkatan produksi ASI pada kelompok yang mendapatkan Endorphin Massage dibandingkan kelompok kontrol.

Kesimpulan: Terdapat pengaruh metode Endorphin Massage terhadap pengeluaran ASI pada ibu post partum

Saran diharapkan kepada petugas kesehatan agar dapat menerapkan metode Endorphin Massage kepada ibu post partum dalam upaya meningkatkan produksi ASI.

Kata Kunci: Endorphin Massage,Pengeluaran ASI 


\section{JKM (Jurnal Kebidanan Malahayati),Vol 7,No.3.Juli 2021, ISSN (Print) 2476-8944 ISSN (Online) 2579-762X, Hal 548-554}

\section{PENDAHULUAN}

Organisasi Kesehatan Dunia (WHO) merekomendasikan pemberian ASI eksklusif pada enam bulan pertama kehidupan bayi. Secara epidemiologi di negara maju, menyusui melindungi bayi dari gastroenteritis, gangguan pernapasan, infeksi telinga, infeksi saluran kemih, alergi, diabetes mellitus, sindrom kematian bayi mendadak, obesitas dan meningkatkan kecerdasan. Menyusui secara eksklusif memberikan manfaat kesehatan bagi wanita juga bermanfaat sebagai kontrasepsi bagi ibu post partum yaitu metode amenore laktasi, lebih cepat kembali ke berat badan sebelum hamil, mencegah osteoporosis, kanker ovarium, kanker payudara dan Rahim (Anderson, Kynoch, \& Kildea, 2016).

ASI memiliki peran penting untuk menunjang pertumbuhan, kesehatan, dan kelangsungan hidup. Di Indonesia, mendorong pemberian ASI Eksklusif untuk bayi hingga usia 6 bulan pertama kehidupannya dan berlanjut hingga anak berusia dua tahun. Pemberian ASI Eksklusif juga dapat menurunkan morbiditas dan mortalitas karena proses menyusui akan merangsang terjadinya kontraksi uterus yang akan mengurangi komplikasi nifas. Bayi yang diberi susu formula kejadian kematian 25 kali lebih tinggi dibandingkan bayi yang diberi ASI eksklusif (I. Lestari, Rahmawati, Windarti, \& Hariyono, 2019)

Cakupan ASI ekslusif di Provinsi Aceh masih rendah yaitu hanya $50 \%$ pada tahun 2016 dan naik menjadi 55\% pada tahun 2017(Dinkes Aceh, 2018), namun kembali turun menjadi $48 \%$ pada tahun 2018 (Dinkes Aceh, 2019). Studi pendahuluan yang dilakukan di Puskesmas Langsa Lama Kota Langsa pada tanggal 18-28 februari 2019, dari 10 (sepuluh) ibu yang melahirkan Puskesmas Langsa Lama Kota Langsa, pada hari pertama persalinan, lima diantaranya $(50 \%)$ pengeluaran $\mathrm{ASI}$ belum lancar/belum keluar sama sekali hal ini disebabkan oleh berbagai hal di antaranya ibu tidak pernah melakukan perawatan payudara selama hamil, rasa stress dan kelelahan setelah proses persalinan.

Tidak semua ibu menyusui mengeluarkan ASI yang cukup untuk bayinya dimana faktor penghambat dalam pemberian ASI adalah produksi ASI itu sendiri (Delima, Arni, \& Ernalinda Rosya, 2016). Faktor-faktor yang menyebabkan rendahnya cakupan pemberian ASI adalah faktor ibu, bayi, dan pelayanan kesehatan psikologis, serta faktor sosial budaya. Beberapa masalah menyusui dapat terjadi termasuk produksi ASI yang tidak adekuat terutama pada beberapa hari pertama kelahiran karena jumlah progesteron, estrogen, dan Prolaktin yang tidak mencukupi dalam tubuh ibu. Keberhasilan pemberian ASI Eksklusif dapat dilihat dari frekuensi, lama menyusui, dan volume produksi ASI (Wahyuni, Setyawan, Ariyanti, Ardiyanto, \& Susanto, 2021). Masalah yang menghambat pemberian ASI pada minggu pertama antara lain produksi ASI yang lebih sedikit. Meningkatkan produksi ASI bisa dilakukan dengan cara merangsang atau memijat payudara (Patimah, Mashoedi, \& Hadisaputro, 2019).

Salah satu kendala dalam memberikan ASI secara dini yaitu produksi ASI yang sedikit pada hari-hari pertama. Massage/pijat merupakan salah satu terapi pendukung yang efektif untuk mengurangi ketidak nyamanan fisik serta memperbaiki mood, pengurangan ketidak nyamanan memberikan efek rileksasi sehingga menstimulasi pengeluaran hormon oksitosin yang membentu proses pengeluaran ASI (Kasmiati \& Sriwidyastuti, 2019). Lama waktu pengeluaran ASI dipengaruhi oleh hormon oksitosin dan hormon prolaktin yang dapat dikeluarkan dengan cara masage endorphin dan oksitosin ini dilakukan dengan belaian lembut terlebih dahulu lalu dilakukan pemijatan di punggung (Hidayati \& Hanifah, 2019). Teknik sentuhan ringan juga membantu menormalkan denyut jantung dan tekanan darah (Wahyuningsih \& Wiwin Rohmawati, 2018).

Tehnik Endorphin Massage yaitu suatu teknik pemijatan ringan pada leher, lengan dan tangan. Dengan adanya pijatan tersebut saraf punggung akan merangsang pengeluaran endorfin di dalam tubuh yang secara tidak langsung akan merangsang refleks oksitosin. Endorphin Massage merupakan sebuah terapi sentuhan/pijatan ringan merangsang tubuh untuk melepaskan senyawa Endorphin yang merupakan pereda rasa sakit dan dapat menciptakan perasaan nyaman (Hartono, Oktaviani, \& Nindya, 2016). Tehnik ini meningkatkan pelepasann hormone endorphine (memberi rasa nyaman dan tenang) dan hormone oksitosin (Ohorella, Sampara, \& Hasriani, 2019). Ketika diberikan massage punggung, saraf punggung akan mengirimkan sinyal ke otak untuk mengeluarkan oksitosin, yang akan menyebabkan kontraksi sel myoepitel yang akan mendorong keluarnya ASI, karena saraf payudara dipersarafi oleh saraf punggung (saraf dorsal) yang menyebar disepanjang tulang belakang. Lancarnya pengeluaran ASI disebabkan juga karena meningkatnya sirkulasi darah pada daerah payudara setelah diberikan massage punggung (Saudina \& Murni, 2019) 


\section{METODOLOGI PENELITIAN}

Jenis penelitian yang digunakan adalah Quasi experiment design (eksperimen semu) dengan pendekatan post test only control group design. Penelitian ini dilakukan di wilayah kerja Puskesmas Langsa Lama Kota Langsa, pada bulan April s/d Juni 2019. Populasi dalam penelitian ini adalah seluruh ibu post partum yang ada di wilayah Puskesmas Langsa Lama Kota Langsa sebanyak 420 orang. Sampel dalam penelitian ini ibu post partum hari pertama sampai dengan hari ke-4. Pemilihan sampel sesuai dengan kriteria inklusi yaitu Ibu postpartum mampu berkomunikasi dengan baik. Adapun kriteri eksklusi adalah Ibu yang melahirkan dengan keadaan bayi meninggal, melahirkan secara sectio caesarea, ibu mengalami kelainan anatomi seperti memiliki kelainan pada puting susu. Jumlah sampel penelitian sebanyak 20 responden (masing-masing 10 responden untuk kelompok perlakuan dan kontrol) Teknik pengambilan sampel yaitu Purposive Sampling. Endorphin Massage dilakukan pijatan di daerah punggung mulai dari batas leher sampai batas bawah scapula di sekitar ruas tulang belakang. Frekuensi Endorphin Massage pada setiap responden dilakukan sebanyak 5 kali dengan durasi 3-5 menit dengan jarak waktu antara masase 30 menit Analisa data yang digunakan adalah univariat (distribusi frekuesi) dan bivariat (Uji Independet T-Test).

HASIL DAN PEMBAHASAN

Analisa Univariat

Tabel 1.

Karakteristik responden

\begin{tabular}{lcc}
\hline Karakteristik & Frekuensi (f) & Persentase (\%) \\
\hline Usia & & \\
$<20$ & 4 & 20 \\
$20-35$ & 13 & 65 \\
$>35$ & 3 & 15 \\
Tingkat & & \\
Pendidikan & 7 & 35 \\
Dasar & 8 & 40 \\
Menengah & 5 & 25 \\
Tinggi & & \\
Paritas & & \\
Primipara & 9 & 45 \\
Multipara & 11 & 55 \\
\hline \multicolumn{1}{c}{ Total } & 20 & 100 \\
\hline
\end{tabular}

Berdasarkan hasil penelitian didapatkan karakteristik responden sebagai berikut:

Berdasarkan tabel 1 diketahui mayoritas usia responden yaitu 20-35 tahun sebanyak 13 responden $(65 \%)$, dengan tingkat pendidikan tinggi 5 responden $(25 \%)$ dan Paritas Primipara sebanyak 9 responden $(45 \%)$.

\section{Analisa Bivariat}

Tabel 2.

Uji Normalitas

\begin{tabular}{lcl}
\hline \multicolumn{1}{c}{ Kelompok } & Sig & \multicolumn{1}{c}{ Kemaknaan } \\
\hline Endorphin & 0,276 & $\begin{array}{l}\text { Berdistribusi } \\
\text { Normal }\end{array}$ \\
Konssage & 0,441 & $\begin{array}{l}\text { Berdistribusi } \\
\text { Normal }\end{array}$ \\
\hline
\end{tabular}

Hasil uji Shapiro-wilk didapatkan nilai sig atau $p$-value $(p>0,05)$ baik kelompok perlakuan mapun kontrol hal ini menunjukkan data berdistribusi normal.

Tabel 3.

Uji Homogen

\begin{tabular}{ccc}
\hline \multicolumn{1}{c}{ Kelompok } & Sig & Kemaknaan \\
\hline $\begin{array}{l}\text { Endorphin Massage } \\
\text { Kontrol }\end{array}$ & 0,963 & Homogen \\
\hline
\end{tabular}

Berdasarkan hasil uji homogen diperoleh nilai signifikansi (sig) sebesar 0963. ( $p=\geq 0.05$ ) maka dapat disimpulkan bahwa kedua kelompok tersebut adalah sama atau homogen.

Tabel 4.

Hasil uji Independen T test Endorphin Massage Pengeluaran ASI pada Ibu Post Partum

\begin{tabular}{lccc}
\hline Kelompok & Mean & $\begin{array}{c}\text { Mean } \\
\text { difference }\end{array}$ & Sig \\
\hline $\begin{array}{l}\text { Endorphin } \\
\text { Massage }\end{array}$ & 8,50 & 3,60 & 0,000 \\
Kontrol & 4,90 & & \\
\hline
\end{tabular}

Hasil uji independen $T$ test didapatkan nilai rerata kelompok perlakuan Endorphin Massage sebesar 8,50 dan kelompok kontrol 4,90 artinya pengeluaran ASI pada kelompok kontrol lebih rendah dari pada kelompok perlakuan. Terlihat pada tabel 4 dimana pengeluaran ASI pada kelompok Endorphin Massage dan kontrol adalah $0,000(p<0,05)$ yang berarti ada peningkatan pengeluaran ASI yang signifikan. Maka dapat disimpulkan adanya pengaruh pemberian 


\section{JKM (Jurnal Kebidanan Malahayati),Vol 7,No.3.Juli 2021, ISSN (Print) 2476-8944 ISSN (Online) 2579-762X, Hal 548-554}

Endorphin Massage terhadap pengeluaran ASI pada ibu post partum.

\section{PEMBAHASAN}

Hasil penelitian ini menunjukkan adanya peningkatan produksi ASI antara kelompok perlakuan dan kontrol, dimana kelompok Endorphin Massage didapatkan nilai rerata 8,50 pada kelompok intervensi dan 3,60 pada kelompok kontrol dengan 0,000 ( $p=<0,05)$. Penelitian ini sejalan dengan penelitian Alza \& Nurhidayat, (2020) dimana didapatkan nilai Z sebesar -3.178 dengan nilai $p 0.001<a 0.05$. Hal ini menunjukkan terdapat pengaruh endorphin massage terhadap produksi ASI pada ibu post partum. Begitu juga hasil penelitian yang dilakukan oleh Masnig, Fibrila, \& Fairus (2017) hasil yang didapatkan yakni sebesar $94,12 \%$, dengan rerata pengeluarannya 2 hari lebih cepat. Hasil uji mann whitney menunjukkan nilai $p$ value sebesar 0,000 dimana $p$ value $<$ a $(0,05)$. Pijat endorfin terhadap produksi ASI pada hari ke 2 rata-rata keluar adalah 2,22 cc, hari ke $33,61 \mathrm{cc}$, hari ke 4 5,89cc. Hasil Sig a 0,000 $<0,005$ (Syukur, Wahyutri, \& Erma Futri, 2020). Ibu post partum yang mendapatkan perlakuan endorphin massage lebih cepat pengeluaran ASI dibandingkan yang tidak dilakukan. Hasil penelitian lain juga membandingkan dua perlakuan yang dlakukan oleh Wulandari \& Mayangsari (2019), menunjukkan pada kedua kelompok intervensi, yaitu pijat oksitosin dan pijat endorphin sama-sama berpeluang untuk meningkatkan produksi ASI. Hampir seluruhnya ibu nifas yang dilakukan kombinasi stimulasi oksitosin dan endorphin massage tidak mengalami bendungan ASI yaitu sebesar 87.5\% (Kusumaningrum \& Aris, 2016). Begitu juga hasil penelitian Wulandari, Mayangsari, \& Sawitry (2019) pijat oksitosin dan endorphin berpengaruh terhadap peningkatan produksi ASI. Hasil penelitian lain juga menunjukkan ada perbedaan bermakna rata rata kadar hormon prolaktin dan volume ASI pada kelompok intervensi dan kelompik kontrol. Kombinasi metode pijat woolwich dan endorphine berpengaruh terhadap peningkatan kadar hormon prolaktin dan volume ASI ibu postpartum (Erniyat, Supriyana, Rahayu, \& Suhartono, 2014). Pijat endorpin efektif untuk kelancaran produksi ASI pada ibu nifas dibandingkan dengan pijat breastcare (Dewi, Indrayani, \& Rina Khanifah, 2017). Hasil penelitian yang dilakukan di Puskesmas Alianyang Kota Pontianak menggunakan uji wilcoxon nilai $\mathrm{P}=0,000$ $<0,05$, terdapat perbedaan peningkatan jumlah pengeluaran ASI ibu nifas sebelum dan sesudah diberikan intervensi berupa diberikan pijat oksitosin dan endorphin (Fitriani, Pangestu, \& Hartikasih, 2021). Peningkatan produksi ASI pada ibu postpartum dapat dilakukan melalui salah satu intervensi keperawatan yang disebut stimulasi pijat endorphin, oksitosin, dan sugestif (SPEOS) (Arsi, Rejeki, \& Juniarto, 2021). Metode SPEOS berpengaruh pada produksi susu dan peningkatan berat badan bayi (Nugraheni \& Heryati, 2017). Produksi ASI sebelum dilakukan metode SPEOS paling rendah adalah $110 \mathrm{ml}$ dan Produksi ASI sesudah dilakukan metode SPEOS rata-rata adalah 129,63 ml (Elisa, Septiariani, \& Lestari, 2018). Metode Stimulasi Pijat Endorphin, Oksitosin dan Sugestif (SPEOS) akan lebih efektif apabila melibatkan suami (N. W. Lestari, Susmiati, \& Fajria, 2020).

Penelitian yang dilakukan oleh Widayanti, Soepardan, Kholifah, Wahyuningsih, \& Yuliastuti, (2016), metode SPEOS (Stimulation of Endorphin, Oxytocin and Suggestive) memberikan hasil peningkatan produksi ASI pada ibu post partum. Hasil penelitian literature review yang dialkukan oleh Katmini \& Sholichah (2020) dari 20 jurnal yang dipilih terdapat 4 jurnal yang menggunakan pijat laktasi dan 16 jurnal yang relevan dengan judul penelitian penulis. Dari 20 jurnal diatas dapat disimpulkan bahwa pijat terapi secara efektif dapat meningkatkan produksi ASI. Terapi pijat sederhana dapat dilakukan sesuai kebutuhan ibu nifas. Terapi pijat merupakan intervensi yang mudah dan aman dilakukan pada ibu nifas. Intervensi ini juga bisa dilakukan oleh suami atau keluarga pasien setelah dilatih oleh bidan / tenaga kesehatan. Begitu juga hasil penelitian Sari, \& Rohmayanti (2017, dilakukan metode SPEOS dapat dilihat bahwa 100\% kelompok yang mendapatkan intervensi produksi ASI dalam kategori cukup. $P$ value adalah 0,000, hal ini berarti $p<0,005$ yang menunjukkan bahwa ada perbedaan produksi ASI yang signifikan sebelum dan setelah dilakukan metode SPEOS pada kelompok intervensi.

Hasil penelitian Saudia \& Murni (2017), menemukan adanya perbedaan yang signifikan produksi ASI sebelum dan setelah diberikan Endorphin massage $(p=0,000)$. Artinya, ada pengaruh Endorphin massage terhadap peningkatan Produksi ASI atau dengan kata lain, pemberian Endorphin massage terbukti efektif meningkatkan produksi ASI pada ibu yang terdeteksi postpartum blues.

Salah satu upaya yang dapat dilakukan untuk meningkatkan produksi ASI adalah melalui endorphin massage. Pemberian massage pada punggung lebih efektif daripada kompres hangat payudara untuk meningkatkan produksi ASI. Hal ini 
dikarenakan, saat dimassage saraf punggung akan merangsang pengeluaran endorphin di dalam tubuh yang secara tidak langsung akan merangsang refleks oksitosin. Ketika diberikan masase punggung, saraf punggung akan mengirimkan sinyal ke otak untuk mengeluarkan oksitosin, yang akan menyebabkan kontraksi sel myoepitel yang akan mendorong keluarnya ASI karena saraf payudara dipersarafi oleh saraf punggung (saraf dorsal) yang menyebar disepanjang tulang belakang. Efek massage juga dapat meningkatkan kadar serotonin dan dopamine sehingga memicu penurunan ketidaknyamanan, kelelahan, stres dan depresi. Kondisi ini sama yang dirasakan oleh subjek setelah dilakukan massage punggung yaitu merasa rileks dan nyaman (Alza \& Nurhidayat, 2020).

Ibu post partum yang telah diberikan masase endorphin terbukti dapat meningkatkan produksi ASI dibandingkan dengan yang tidak diberikan produksi ASI hal ini dikarenakan selama diberikan masase endorphin ibu juga diberikan motivasi untuk menyusui bayinya sehingga merasa lebih nyaman dan merasa lebih percaya diri untuk menyusui bayinya sehingga memperlancar pengeluaran ASI pada ibu (Pratimi, Ernawati, \& Saudia, 2020). Selain itu upaya yang dapat dilakukan untuk memberikan kelancaran ASI ibu nifas yaitu dengan pemijatan endhorpin yang dilakukan oleh tenaga kesehatan maupun suami. Peran suami nyatanya tidak hanya membuat proses pemberian ASI menjadi lebih lancar (Khasanah, Widyastuti, \& Maharani, 2021).

Peneliti berasumsi bahwa tidak semua ibu post partum langsung mengeluarkan ASI pada saat post partum, karena pengeluaran ASI merupakan interaksi yang sangat kompleks antara rangsangan mekanik, saraf dan bermacam macam hormon yang berpengaruh terhadap pengeluaran oksitosin. Sehingga sangat dibutuhkan tehnik pijatan yang dapat membantu pengeluaran ASI, salah satunya adalah tehnik Endorphin Massage.

\section{SIMPULAN}

Terdapat pengaruh metode Endorphin Massage terhadap pengeluaran ASI pada ibu post partum nilai rerata kelompok perlakuan 8,50 dan kelompok kontrol 4,90 p-value 0,000.

\section{SARAN}

Saran diharapkan penelitian lanjutan membandingkan dua metode massage terhadap pengeluaran ASI pada ibu Post Partum. Diharapkan kepada petugas kesehatan memberikan secara rutin Endorphin Massage untuk meningkatkan produksi ASI selam post partum.

\section{DAFTAR PUSTAKA}

Alza, N., \& Nurhidayat, N. (2020). Pengaruh Endorphin Massage terhadap Produksi ASI pada Ibu Post Partum di Puskesmas Somba Opu Kabupaten Gowa. Jurnal IImiah Kesehatan, 2(2), 93-98. https://doi.org/10.36590/jika.v2i2.61

Anderson, L., Kynoch, K., \& Kildea, S. (2016). Effectiveness of breast massage in the treatment of women with breastfeeding problems: a systematic review protocol. JBI Database of Systematic Reviews and Implementation Reports, 14(8), 19-25. https://doi.org/10.11124/JBISRIR-2016003058

Arsi, R., Rejeki, S., \& Juniarto, A. Z. (2021). Endorphin, Oxytocin, And Suggestive Massage Stimulation (SPEOS) Methods In Increasing Breast Milk Production In Postpartum Mothers. Media Keperawatan Indonesia, 4(2), 140. https://doi.org/10.26714/mki.4.2.2021.14 0-148

Delima, M., Arni, G. Z., \& Ernalinda Rosya. (2016). Pengaruh Pijat Oksitosin Terhadap Peningkatan Produksi Asi lbu Menyusui Di Puskesmas Plus Mandiangin. Jurnal Ipteks Terapan, 4, 283-293.

Dewi, A. P. S., Indrayani, E., \& Rina Khanifah. (2017). Kombinasi Pijat Punggung dan Endorphin Terhadap Produksi Asi Pada lbu Post Partum. Jurnal IImiah Kesehatan Keperawatan, 13(2), 94-98.

Elisa, Septiariani, L. L., \& Lestari, K. P. (2018). Pengaruh Metode SPEOS (Stimulasi Pijat Endorfin Oksitosin Suggestif) Terhadap Produksi ASI Pada Ibu Nifas. Indonesian Journal of Nursing Research (IJNR), 1(2).

Erniyat, S. B. P., Supriyana, Rahayu, S., \& Suhartono. (2014). Pengaruh Kombinasi Metode Pijat Woolwich dan Endorphine Terhadap Kadar Hormon Prolaktin Dan Volume Asi (Studi Pada Ibu Postpartum di Griya Hamil Sehat Mejasem Kabupaten Tegal).

Fitriani, H., Pangestu, J. F., \& Hartikasih, E. (2021). Efektifitas Pijat Oksitosin dan Endorphin Pada Pengeluaran Asi lbu 
Postpartum di Puskesmas Alianyang Kota Pontianak. Jurnal Kebidanan Khatulistiwa, 7(1), 9-14.

Hartono, Oktaviani, A., \& Nindya, D. (2016). Massase Endorphin Terhadap Volume ASI Pada lbu Post Partum. Jurnal Kebidanan, VIII(02).

Hidayati, T., \& Hanifah, I. (2019). Penerapan Metode Massage Endorphin Dan Oksitosin Terhadap Peningkatan Produksi Asi Pada lbu Menyusui Bayi 0-6 Bulan Di Desa Gading Kabupaten Probolinggo. Journal Health of Science, 12(1), 30-38.

Kasmiati, \& Sriwidyastuti. (2019). Pijat Postpartum Terhadap Kecepatan Pengeluaran Air Susu Ibu (ASI). Journal of Widwifery, 1(2), 46-50.

Katmini, K., \& Sholichah, N. M. (2020). Lactation Massage for Increasing Breast Milk Production in Postpartum Mothers. Journal for Quality in Public Health, 4(1), 104-113.

https://doi.org/10.30994/jqph.v4i1.168

Khasanah, Widyastuti, T., \& Maharani, K. (2021). Pengaruh Dukungan Suami Terkait Pijat Endorphin Terhadap Produksi ASI Pada lbu Nifas. IImu Kebidanan, 7(2), 14-18.

Kusumaningrum, A. T., \& Aris, A. (2016). Efektifitas Kombinasi Stimulasi Oksitosin dan Endorfin Massage terhadap Kejadian Bendungan ASI pada Ibu Post Partum Primipara. Jurnal Surya, 08(03), 31-37.

Lestari, I., Rahmawati, I., Windarti, E., \& Hariyono. (2019). SPEOS (Stimulation of endorphin, oxytocin and suggestive): Intervention to improvement of breastfeeding production. Medico-Legal Update, 19(1), 210-215. https://doi.org/10.5958/09741283.2019.00042.2

Lestari, N. W., Susmiati, \& Fajria, L. (2020). Pengetahuan, sikap tentang ASI (Air Susu Ibu) dan keterampilan suami ibu nifas dalam melakukan metode SPEOS (Stimulasi Pijat Endorphin, Oksitosin, dan Sugestif). Holistik Jurnal Kesehatan, 14(3), 321-331. https://doi.org/10.33024/hjk.v14i3.2871

Masnig, Fibrila, F., \& Fairus, M. (2017). Pengaruh Endorphin Massage Terhadap Pengeluaran Asipada Ibu Post Partum, $X(2), 35-40$.

Nugraheni, D. E., \& Heryati, K. (2017). Metode Speos (Stimulasi Pijat Endorphin, Oksitosin dan Sugestif) Dapat Meningkatkan Produksi ASI dan Peningkatan Berat Badan Bayi. Jurnal Kesehatan, 8(1), https://doi.org/10.26630/jk.v8i1.384

Ohorella, F., Sampara, N., \& Hasriani. (2019). Pengaruh Kombinasi Pijat Woolwich Dan Endophine Terhadap Kelancaran ASI Pada Ibu Post Partum Di RSUD Labuang Baji.

Patimah, S., Mashoedi, I. D., \& Hadisaputro, S. (2019). The Effect of Lactapuncture Massage on Breast Milk Production through Prolactin Hormone Levels Changes in Dr. M. Ashari Hospital, Pemalang, Central Java. Indonesian Journal of Medicine, 4(1), 15-20. https://doi.org/10.26911/theijmed.2019.0 4.01.03

Pratimi, B. M. A., Ernawati, \& Saudia, B. E. P. (2020). Pengaruh Masase Endorphin Terhadap Peningkatan Produksi Asi Pada Ibu Post Partum Di Wilayah Kerja Puskesmas Bagu, 8511, 61-69.

Sari, D. P., Rahayu, H. E., \& Rohmayanti. (2017). Pengaruh Metode SPEOS Terhadap Produksi Asi pada lbu Post Seksio Sesarea di Rumah Sakit Umum Daerah Tidar Kota Magelang Tahun 2017, 183-190.

Saudia, B. E. P., \& Murni, N. N. A. (2017). Pengaruh Endorphin Massage Terhadap Peningkatan Produksi Asi Pada lbu Yang Terdeteksi Post Partum Blues Dengan Skrining Epds (Edinburgh Post Partum Depression Scale) Di Puskesmas Wilayah Kerja Sekota Mataram. Jurnal Kesehatan Prima, 11(1), 36-42.

Saudina, B. E. P., \& Murni, N. N. A. (2019). Pengaruh Endorphin Massage Terhadap Peningkatan Produksi ASI Pada Ibu Yang Terdeteksi Post Partum Blues dengan Skrining EPDS (Edinburgh Post 
Partum Depression Scale) di Puskesmas Wilayah Kerja Sekota Mataram. JJurnal Kesehatan Prima, 53(9), 1689-1699. Retrieved from www.journal.uta45jakarta.ac.id

Syukur, N. A., Wahyutri, E., \& Erma Futri. (2020). Pijat Kombinasi Endorfin Oksitosin Mempengaruhi Produksi Asi Pada Ibu Post Operasi Sectio Caesarea. Mahakam Midwifery Journal, 5(1), 5163.

Wahyuni, S., Setyawan, T., Ariyanti, I., Ardiyanto, J., \& Susanto, E. (2021). The success of early breastfeeding by applying SPEOS Key Messages:, 24(01).

Wahyuningsih, E., \& Wiwin Rohmawati. (2018). Efektivitas Pijat Endorpin Dan Pijat Breastcare Terhadap Kelancaran Produksi Asi Pada Ibu Nifas Di Rsu PKU Muhammadiyah Delanggu. Jurnal Involusi Kebidanan, 9(17), 47-60.

Widayanti, W., Soepardan, S., Kholifah, L. N., Wahyuningsih, D., \& Yuliastuti, S. (2016).
SPEOS (Endorphins and Oxytocin Massage Stimulation And Suggestive Provision) Reduced The Duration of Breast Milk Production Among The Puerperal Women In Midwife Private Practitioners Of Cirebon District, 345348.

Wulandari, D. A., \& Mayangsari, D. (2019). Pengaruh Pijat Oksitosin Dan Pijat Endorphin Terhadap Kelancaran Produksi ASI. Jurnal Kebidanan, XI(02), 128-134. Retrieved from file:///C:/Users/asus/Downloads/349-6861-SM.pdf

Wulandari, D. A., Mayangsari, D., \& Sawitry. (2019). Aplikasi Pijat Oksitosin sebagai Penatalaksanaan Kelancaran ASI pada Ibu Menyusui di Bidan Praktik Mandiri Kecamatan Tembalang Application of Oxytocin Massage as Management of Breastfeeding in Independent Practice Midwives Tembalang District World Health, 2, 107-112. 